\title{
Faktor Dominasi Pengembangan Karir terhadap Komitmen Organisasi
}

\author{
Yoga Satria Widjaya*, Ratna Indrawati*, Cri S Prajna Wekadigunawan* \\ *Program Studi Manajemen Administrasi Rumah Sakit, Universitas Esa Unggul \\ yogaswidjaja@gmail.com
}

\begin{abstract}
Low commitment from employees to the hospital could be seen from the low number of employees who remain working. Compensation did not match expectations and the work climate was uncomfortabel and the lack of training as one of the career development processes made the low commitment of employees to the hospital. This study aims to provide empirical evidence of the effect of compensation and work climate on organizational commitment mediated by career development. The research method used will be quantitative methods with the type of causality research. Data source will be primary. Subjects to be analyzed will be all employees except the doctors in $X$ hospital Cisauk Tangerang. Analysis will be using structural path analysis. Results of this study were compensation, work climate, and career development simultaneously have a positive and significant effect on organizational commitment. Partially, compensation and work climate had a positive and significant effect on career development. The research findings were the direct effect of compensation and work climate on organizational commitment greater than mediated by career development. The effect of career development is greater on organizational commitment compared to compensation and work climate.
\end{abstract}

Keywords : career development, compensation, healthcare, hospital, organizational commitment, work climate

\section{PENDAHULUAN}

Keberhasilan setiap organisasi dapat dilihat dari elemen-elemen desain pekerjaan yang digabungkan dengan komitmen organisasi dan mengarah pada kompensasi yang baik untuk para pekerjanya. Memiliki tenaga kerja yang berkomitmen merupakan keuntungan bagi organisasi manapun. Karyawan yang berkomitmen dengan tujuan organisasi akan merasa yakin dan percaya bahwa nilai-nilai dan tujuan organisasi sejalan dengan harapan karyawan sehingga muncul kepuasan kerja. Untuk itu kejelasan tujuan dan kebijakan yang diterapkan oleh organisasi merupakan faktor yang sangat penting dan perlu diterapkan dengan baik dan benar sehingga komitmen karyawan terhadap organisasi dapat semakin tumbuh.

Faktor-faktor yang mempengaruhi komitmen kerja seperti pengembangan karir, kompensasi, lingkungan dan kondisi kerja, semangat kerjasama, dan hubungan dengan manajemen. Komitmen kerja karyawan akan terbentuk apabila karyawan merasa dirinya memiliki ruang untuk mengembangkan karirnya dalam perusahaan. Selain itu, lingkungan dan kondisi kerja yang nyaman dan kebijakan promosi jabatan yang transparan, serta kompensasi yang tinggi adalah merupakan hal-hal yang diinginkan karyawan. ${ }^{1}$

Perkembangan sektor bisnis mengalami pertumbuhan yang sangat pesat, baik bisnis yang bergerak di bidang manufaktur maupun 
jasa. Perkembangan perekonomian secara menyeluruh yang diiringi dengan perkembangan teknologi dan ilmu pengetahuan menciptakan sebuah persaingan yang semakin ketat dan tajam, baik di pasar domestik maupun di pasar internasional. Dewasa ini sektor jasa telah mengalami perkembangan yang sangat pesat. Demikian pula pada industri jasa kesehatan baik sektor Rumah Sakit maupun Puskesmas, mulai hidup dan berkembang sehingga diperlukan peningkatan kualitas pelayanan. Semakin tingginya tingkat pendidikan masyarakat menyebabkan masyarakat semakin sadar akan pentingnya kualitas kesehatan yang diharapkan.

Melihat bahwa output seringkali berbanding lurus dengan kualitas input (termasuk dalam jasa kesehatan), peneitian ini melakukan presurvey di rumah sakit X Cisauk Tangerang terdapat beberapa masalah pada kompensasi seperti gaji yang tidak sesuai upah minimum regional (UMR) dan tidak ada insentif serta tunjangan baik tunjangan makan, transport ataupun kesehatan. Untuk iklim kerja, hubungan kerja antara sesama karyawan dan atasan banyak yang menyatakan setuju terjalin dengan baik. Untuk fasilitas yang mendukung pekerjaan, banyak karyawan menyatakan rumah sakit kurang menyediakan fasilitas yang mendukung pekerjaan mereka. Seluruh karyawan menjawab ingin karir di luar rumah sakit X Cisauk Tangerang karena tidak ada penghargaan yang diberikan oleh rumah sakit untuk prestasi yang mereka lakukan. Tingkat komitmen karyawan juga masih rendah. Hal ini dapat diketahui dari banyaknya karyawan yang merasa tidak sulit meninggalkan rumah sakit untuk mencari karir yang lebih baik dan hampir seluruh karyawan tidak ingin menghabiskan sisa karir di rumah sakit $\mathrm{X}$ Cisauk Tangerang.

Kondisi tersebut membuat rumah sakit sulit bertahan. Padahal sumber daya manusia merupakan bagian terpenting dan aset yang sangat berharga yang harus dikelola dengan baik oleh perusahaan agar dapat memberikan kontribusi yang optimal bagi perusahaan dan demi tercapainya tujuan perusahaan. Sebagai sumber daya terpenting, perusahaan harus dapat bersikap adil kepada semua karyawannya. $^{2}$

Kondisi adil dalam lingkungan kerja adalah kondisi dimana pekerja mendapat kesempatan dan perlakuan yang sama dalam melaksanakan pekerjaannya. Suatu organisasi memerlukan ketersediaan sumber daya manusia yang handal untuk tumbuh dan berkembang. Upaya penyediaan sumber daya manusia yang handal dapat diperoleh melalui peningkatan kualitas sumber daya manusia melalui program perencanaan karir, pelatihan dan pengembangan karir yang mendorong tercapainya kinerja yang baik, sehingga dapat memberikan peningkatan produktivitas pada organisasi. Karyawan membutuhkan penyesuaian diri terhadap lingkungan kerja, menyelaraskan kemampuan diri terhadap perkembangan teknologi dan perkembangan regulasi dalam dunia kerja merupakan sasaran dari perencanaan karir, pelatihan dan pengembangan karir karyawan, sehingga pegawai memiliki kinerja lebih baik dalam menjalankan tugas-tugasnya. ${ }^{3}$

Program perencanaan karir, pelatihan dan pengembangan karir dapat meningkatkan keterampilan, pengetahuan dan pengalaman karyawan terhadap pekerjaannya. Namun, tidak semua organisasi mampu memberikan pelatihan untuk karyawannya. Manajemen rumah sakit $\mathrm{X}$ Cisauk Tangerang jarang mengadakan diklat bagi karyawannya. Pada tahun 2019, pihak manajemen hanya sekali mengadakan pelatihan bagi karyawannya. Harapan dari karyawan dengan adanya pelatihan akan memberikan peningkatan keterampilan dan jenjang karir. Pengembangan karir yang berupa pendampingan dan peningkatan kualitas pekerjaan dapat meningkatkan komitmen karyawan. ${ }^{4}$ Studi ini merekomendasikan manajer sumber daya manusia harus memasukkan mentoring dan peningkatan kualitas pekerjaan sebagai faktor-faktor yang dapat meningkatkan pengembangan karir karyawan mereka yang nantinya meningkatkan komitmen mereka untuk mencapai tujuan organisasi. 
Peningkatan komitmen karyawan dapat juga dilakukan dengan memberikan reward yang berupa kompensasi. Kompensasi dapat berupa pendapatan yang berbentuk uang, barang langsung atau tidak langsung yang diterima pegawai sebagai imbalan atas jasa yang diberikan kepada perusahaan. ${ }^{5}$ Kompensasi tidak langsung merupakan pemberian keuntungan bagi pekerja di luar gaji atau upah tetap. Kompensasi tidak langsung bisa berupa program pemberian penghargaan atau ganjaran dengan variasi yang kompleks. Kompensasi tidak langsung juga bisa diartikan sebagai balas jasa (pelengkap) atau tunjangan yang diberikan dalam bentuk "pelayanan" terhadap karyawan karena diperlakukan sebagai upaya penciptaan kondisi lingkungan kerja yang menyenangkan. Jenis yang satu ini juga bisa berwujud uang yang diberikan melalui pihak ketiga. Misalnya, perusahaan mengikutsertakan para karyawannya dalam program perlindungan sosial dan kesehatan. Jadi, perusahaanlah yang membayarkan premi atas asuransi yang disediakan perusahaan untuk para karyawannya seperti asuransi jiwa, asuransi kesehatan, asuransi ketenagakerjaan, sehingga karyawan dapat menikmati manfaat dari program-program tersebut. Selain itu, fasilitas seperti mobil dinas, akses internet, voucher, keanggotaan klub, fasilitas cuiti, akomodasi dinas luar dan sebagainya.

Menilik pada kasus nyata yang pernah terjadi pada Rumah Sakit ini pernah terjadi permasalahan pada kompensasi yang membuat salah satu karyawannya mengajukan pengunduran diri. Alasannya adalah gaji pokok yang belum sesuai dengan upah minimum regional, uang lembur yang terlalu kecil, dan insentif yang sedikit. Menurut Daniel, manajemen kompensasi secara positif mempengaruhi komitmen mereka untuk mencapai tujuan organisasi. ${ }^{6}$ Dapat juga dikatakan bahwa manajemen kompensasi mengarah pada kinerja yang lebih baik, peningkatan manajemen, hubungan kerja yang baik antara pengusaha dan karyawan dan meningkatkan komitmen organisasi di tempat kerja.
Komitmen organisasi selain dipengaruhi oleh kompensasi, kompetensi, pengembangan karir, juga dipengaruhi oleh iklim kerja. Iklim kerja merupakan salah satu faktor fisik yang berpotensi menimbulkan gangguan kesehatan bagi karyawan bila berada dalam kondisi yang ekstrim. Dalam suatu lingkungan kerja, tenaga kerja akan menghadapi tekanan lingkungan. Tekanan lingkungan tersebut dapat berasal dari kimia, fisik, biologis dan psikis. Tekanan lingkungan kerja fisik khususnya lingkungan kerja panas memegang peranan yang penting, oleh karena itu lingkungan kerja harus diciptakan senyaman mungkin supaya didapatkan efisiensi kerja dan kesehatan karyawan tetap terjaga. Lingkungan yang sehat berpengaruh postif signifikan terhadap komitmen organisasi ${ }^{7}$.

Merujuk pada Peraturan Menteri Kesehatan Republik Indonesia Nomor 4 tahun 2018 mengenai Kewajiban Rumah Sakit butir pasal 2 bahwa Rumah Sakit wajib memberi pelayanan kesehatan yang aman, bermutu, antidiskriminasi, dan efektif dengan mengutamakan kepentingan pasien sesuai dengan standar pelayanan Rumah Sakit. Namun hasil pengamatan langsung yang dilakukan oleh peneliti di rumah sakit $\mathrm{X}$ Cisauk Tangerang didapatkan kondisi kebersihan di rumah sakit kurang karena memilki aroma kurang sedap, banyak fasilitas penunjang pada ruang rawat rumah sakit yang seharusnya juga diperbaiki seperti Pendingin Udara (Air Conditioner) karena temperatur ruangan terasa panas terutama pada ruang poliklinik rawat jalan, serta kursi-kursi ruang tunggu yang harus diganti. Pada ruang perawatan kebersihan juga tidak terjaga dengan baik dimana koridor ruang perawatan kotor dan banyak sandal/sepatu yang berantakan dan tidak disediakan lemari atau rak untuk tempat penyimpanan sandal/sepatu pengunjung.

Berdasarkan hasil pengamatan dapat dilihat lingkungan kerja yang kurang bersih serta panas menyebabkan ketidaknyaman dalam bekerja. Berdasarkan Peraturan Menteri Kesehatan nomor 7 tahun 2019 mengenai Kesehatan Lingkungan Rumah Sakit (pasal 2) bahwa standar baku mutu 
kesehatan lingkungan dan persyaratan kesehatan rumah sakit ditetapkan pada media lingkungan yang meliputi: air, udara, tanah, pangan, sarana dan bangunan, vektor dan binatang pembawa penyakit.

Berdasarkan uraian di atas, tingginya komitmen dapat membawa rumah sakit berkembang ke arah yang lebih baik sehingga diperlukan pengembangan faktor-faktor yang mendukungnya. Tujuan dalam penelitian ini adalah untuk menganalisa pengaruh variabel kompensasi dan iklim kerja terhadap komitmen organisasi dengan pengembangan karir sebagai variabel intervening di rumah sakit X Cisauk Tangerang.

\section{METODE PENELITIAN}

Penelitian ini menggunakan teknik analitis kuantitatif dengan desain kausalitas., Penelitian ini telah dilakukan pada bulan Februari sampai dengan Maret 2020. Populasi pada penelitian ini adalah keseluruhan karyawan RS X Cisauk Tangerang berjumlah 100 responden Teknik non probability sampling merupakan teknik yang diterapkan dalam penelitian ini. Selain itu penelitian ini juga menggunakan metode purposive sampling dengan menerapkan kriteria inklusi dan eksklusi. Pada penelitian yang dikategorikan dalam kriteria responden ekslusi adalah tenaga dokter, sedangkan kriteria responden inklusi adalah seluruh karyawan $\mathrm{RS} X$ Cisauk Tangerang, kecuali tenaga dokter. Instrumen penelitian yang digunakan dalam penelitian ini adalah kuesioner dengan skala likert. Jumlah sampel pada penelitian ini sebanyak 94 responden.

Variabel independen dalam penelitian ini adalah variabel kompensasi dan iklim kerja. Variabel dependen pada penelitian ini adalah variabel pengembangan karir dan kompensasi. Namun variabel pengembangan karir pada penelitian ini juga sebagai variabel intervening. Penelitian ini terdiri dari 6 hipotesis, yaitu:

H1 : Terdapat pengaruh kompensasi, iklim kerja terhadap komitmen organisasi dengan pengembangan karir sebagai variabel intervening,

H2 : Terdapat pengaruh kompensasi terhadap pengembangan karir,

H3 : Terdapat pengaruh iklim kerja terhadap pengembangan karir,

H4 : Terdapat pengaruh pengembangan karir terhadap komitmen organisasi,

H5 : Terdapat pengaruh kompensasi terhadap komitmen organisasi,

H6 : Terdapat pengaruh iklim kerja terhadap komitmen organisasi.

Uji validitas menggunakan Pearson Product Moment Correlation, dimana suatu variabel dikatakan valid jika nilai $r$ hitung $>r$ tabel, hasil uji reliabilitas dengan menggunakan uji Cronbach Alpha $(\alpha)>0,6$, diperoleh hasil bahwa variabel kompensasi, iklim kerja, pengembangan karir dan komitmen organisasi semua reliabel. Analisis data dalam penelitian ini menggunakan model path analysis-AMOS (Gambar 1).

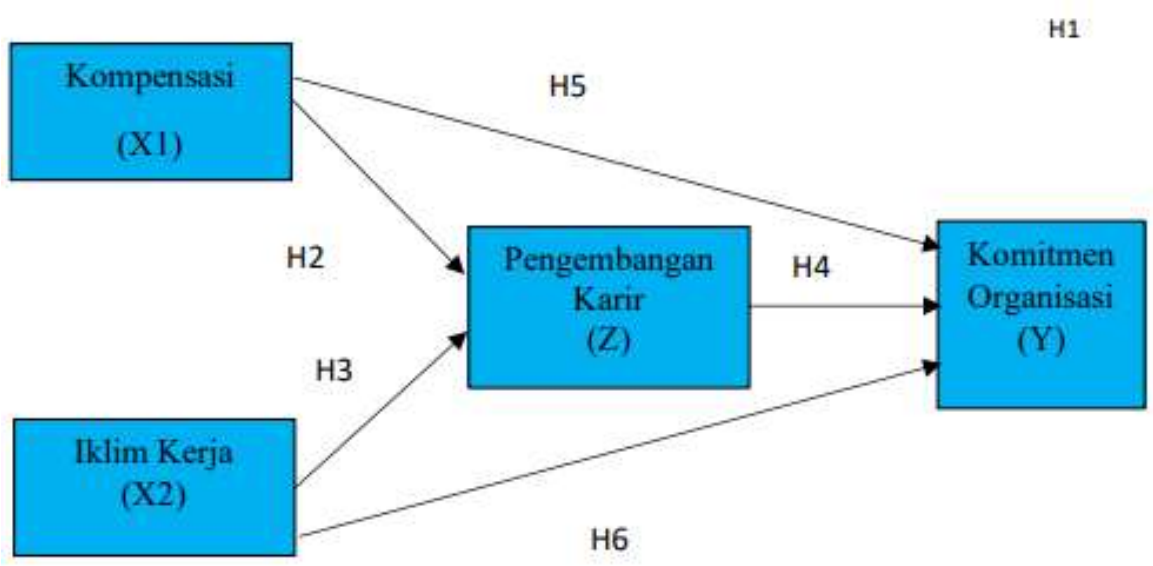

Gambar 1. Model path analysis 


\section{HASIL DAN PEMBAHASAN}

Jumlah responden yang diteliti di rumah sakit X Cisauk Tangerang sebanyak 94 responden. Dimana jumlah responden perempuan lebih banyak dari responden lakilaki dengan persentase responden perempuan yaitu 75 orang $(80 \%)$ dan laki-laki 19 orang (20\%). Sebagian besar usia responden 20-30 tahun sebanyak 64 orang $(68 \%)$. Sebagian besar responden memiliki pendidikan D3 sebanyak 47 orang $(50 \%)$. Untuk unit kerja perawat sebanyak $34 \%$, bidan $7,5 \%$ dan unit lain seperti umum dan penunjang medis sebanyak 58,5\%. Berdasarkan lama kerja sebanyak 40 orang responden bekerja $<1$ tahun $(42,5 \%), 1-5$ tahun 30 orang $(32 \%)$ dan $>5$ tahun 24 orang $(25,5 \%)$. Hasil deskripsi jawaban responden tentang sikap dalam berperilaku ditunjukkan dalam matriks perilaku dalam Tabel 1.

Tabel 1. Matriks tanggapan responden RS X Cisauk Tangerang

\begin{tabular}{|c|c|c|c|c|}
\hline \multirow{2}{*}{ Variabel } & \multicolumn{4}{|c|}{ Posisi Tanggapan Responden } \\
\hline & Rendah & Sedang & Tinggi & Perilaku \\
\hline Kompensasi & & * & & $\begin{array}{c}\text { Kurang } \\
\text { Puas }\end{array}$ \\
\hline Iklim Kerja & & $*$ & & $\begin{array}{l}\text { Kurang } \\
\text { nyaman }\end{array}$ \\
\hline $\begin{array}{l}\text { Pengembangan } \\
\text { Karir }\end{array}$ & & & $*$ & Terbuka \\
\hline $\begin{array}{l}\text { Komitmen } \\
\text { Organisasi }\end{array}$ & & $*$ & & Normal \\
\hline
\end{tabular}

Berdasarkan Tabel 1 maka didapat tanggapan responden terhadap kompensasi, iklim kerja, pengembangan karir dan komitmen organisasi. Kompensasi yang diberikan oleh rumah sakit $\mathrm{X}$ Cisauk Tangerang dianggap kurang memuaskan oleh karyawan dan iklim kerja juga dirasakan kurang nyaman dikarenakan fasilitas untuk pekerjaan kurang mendukung. Pada pengembangan karir sudah ada sistem yang dibuat oleh rumah sakit dan sudah cukup baik, tetapi sistem promosi yang dilakukan belum sesuai harapan karyawan sehingga berpengaruh terhadap komitmen yang dimiliki karyawan hanya pada tahap normal, tidak kuat.

\section{Uji Normalitas dan Multikolinieritas}

Ada jawaban responden yang terlalu ekstrim sehingga tidak bisa olah. Untuk itu sampel yang dapat digunakan sebanyak 93 sampel. Uji normalitas menguji apakah dalam sebuah model analisis jalur, variabel dependen atau independent atau bahkan keduanya mempunyai distribusi normal atau tidak normal. Untuk mendeteksi normalitas secara bersama-sama (multivariate), dapat dilihat dari nilai cr dari kurtosis pada baris terakhir lebih kecil dari \pm 2.58 . Pada Tabel 2 dapat dilihat nilai cr pada kurtosis baris terakhir adalah 1,503.

Tabel 2. Data uji normalitas

\begin{tabular}{lllrrrr}
\hline \multicolumn{1}{c}{ Variabel } & Min & Max & Skew & Cr & Kurtosis & \multicolumn{1}{c}{ cr } \\
\hline Kompensasi & 2.000 & 5.000 &,- 486 & .609 &,- 001 &,- 001 \\
Iklim kerja & 1.000 & 4,500 &, 354 & 1,395 &,- 835 & $-1,644$ \\
Karir & 2,620 & 4,770 &,- 052 &,- 206 & 1.001 & 1,970 \\
Komitmen & 2.560 & 4,780 &, 279 & 1,098 &, 500 &, 984 \\
Multivariate & & & & & 2,160 & $\mathbf{1 , 5 0 3}$ \\
\hline
\end{tabular}

Uji multikolinieritas dilakukan dengan melihat determinan matrikx kovarians. Jika nilainya sangat kecil mengindikasikan terjadinya multikolinearitas. Dalam penelitian ini didapatkan nilai determinan matriks kovarian hasilnya 0.002 (hasil positif dan lebih besar dari 0.000) artinya tidak ada multikolinearitas.

\section{Uji Parsial dan Simultan}

Tabel 3 menunjukkan pengaruh antar variabel baik secara parsial maupun secara keseluruhan (simultan). Hasil pengujian menyatakan bahwa semua pengujian hipotesis diterima. Nilai estimate pada Tabel 3 memperlihatkan bahwa variabel independent berpengaruh positif terhadap variabel dependen sedangkan pada $p$ value membuktikan bahwa variabel independen berpengaruh signifikan terhadap variabel dependen. Ketika kompensasi ditingkatkan maka meningkatkan keinginan karyawan untuk mengembangan karir di organisasi itu. Faktor lain yang mempengaruhi keinginan pengembangan karir adalah iklim kerja yang baik. Peningkatan pengembangan karir bagi 
karyawan, kompensasi, dan iklim kerja akan meningkatkan komitmen karyawan untuk tetap bekerja di rumah sakit $\mathrm{X}$ Cisauk Tangerang.

Tabel 3. Uji Hipotesa

\begin{tabular}{|c|c|c|c|c|c|}
\hline Variabel & Estimate & S.E. & C.R. & $P$ & Ket \\
\hline $\begin{array}{l}\text { Kompensasi } \\
\text { terhadap } \\
\text { karir }\end{array}$ & 0,206 & 0,049 & 4,181 & ,006 & $\begin{array}{c}(\mathrm{H} 2) \\
\text { Diterima }\end{array}$ \\
\hline $\begin{array}{l}\text { Iklim kerja } \\
\text { terhadap } \\
\text { karir }\end{array}$ & 0,219 & 0,056 & 3,931 & $* * *$ & $\begin{array}{c}(\mathrm{H} 3) \\
\text { Diterima }\end{array}$ \\
\hline $\begin{array}{l}\text { Karir } \\
\text { terhadap } \\
\text { komitmen }\end{array}$ & 0,440 & 0,096 & 4,577 & $* * *$ & $\begin{array}{c}(\mathrm{H} 4) \\
\text { Diterima }\end{array}$ \\
\hline $\begin{array}{l}\text { Kompensasi } \\
\text { terhadap } \\
\text { komitmen }\end{array}$ & 0,161 & 0,049 & 3,266 & $* * *$ & $\begin{array}{c}\text { (H5) } \\
\text { Diterima }\end{array}$ \\
\hline $\begin{array}{l}\text { Iklim kerja } \\
\text { terhadap } \\
\text { komitmen }\end{array}$ & 0,143 & 0,055 & 2,600 & ,003 & $\begin{array}{c}(\mathrm{H} 6) \\
\text { Diterima }\end{array}$ \\
\hline $\begin{array}{l}\text { Kompensasi, } \\
\text { iklim kerja } \\
\text { dan karir } \\
\text { terhadap } \\
\text { komitmen }\end{array}$ & & \multicolumn{3}{|c|}{$\begin{array}{c}\text { Chi-square } 0.009 \\
\text { P 0,924 }\end{array}$} & $\begin{array}{c}(\mathrm{H} 1) \\
\text { Diterima }\end{array}$ \\
\hline
\end{tabular}

\section{Pengaruh Kompensasi dan Iklim Kerja terhadap Komitmen Organisasi dengan Pengembangan Karir sebagai Variabel Intervening}

Berdasarkan uji koefisien determinasi $\left(\mathrm{R}^{2}\right)$, nilai yang didapatkan dari variabel kompensasi, iklim kerja dan pengembangan karir terhadap komitmen organisasi adalah sebesar 0.561, yang berarti variabel kompensasi, iklim kerja dan pengembangan karir mempengaruhi komitmen organisasi sebesar $56,1 \%$, sedangkan sisanya $43,9 \%$ dipengaruhi oleh variabel lain di luar penelitian ini seperti budaya kerja dan loyalitas karyawan. Berdasarkan hasil analisa distribusi responden dengan menggunakan three box method, responden banyak mengungkapkan mereka diajari untuk setia kepada rumah sakit tempat mereka bekerja, tetapi jika ditawari di tempat yang lebih baik, mereka juga akan meninggalkan rumah sakit tersebut. Artinya karyawan sudah memiliki kepercayaan untuk berkomitmen pada rumah sakit tapi belum kuat karena sebagian besar karyawan memilih untuk meninggalkan rumah sakit apabila ditawari pekerjaan di tempat lain yang lebih baik.

Pada indikator yang lain, responden banyak yang tidak setuju untuk meneruskan karir di rumah sakit ini, namun walaupun demikian banyak di antara responden tidak dapat meninggalkan rumah sakit walaupun mereka ingin, karena mereka akan mengorbankan manfaat yang diberikan rumah sakit dan hal ini tidak akan mereka dapatkan di rumah sakit lain. Artinya komitmen karyawan masih rendah karena mereka merasakan kurang dapat mengembangkan karir di rumah sakit ini, dan karyawan dapat dengan mudah pindah ke rumah sakit lain yang menawarkan pekerjaan lebih baik.

Budiningsih et al ${ }^{8}$ menyatakan bahwa pengembangan karir dan kompensasi berpengaruh secara positif dan signifikan terhadap kepuasan kerja. Kepuasan kerja dan pengembangan karir berpengaruh terhadap komitmen organisasional secara positif dan signifikan. Pengaruh kompensasi terhadap komitment organisasional berpengaruh secara positif dan signifikan. Pengembangan karir dan kompensasi berpengaruh secara tidak langsung terhadap komitmen organisasional melalui kepuasan kerja secara positif dan signifikan. Pada penelitian yang dilakukan oleh Solihin et al ${ }^{9}$, hasil studi ini mengungkapkan bahwa kompensasi dan pengembangan karir memiliki efek positif yang signifikan terhadap komitmen organisasi baik secara parsial maupun simultan. Kompensasi hasil lainnya dan pengembangan karir tidak berpengaruh signifikan terhadap intensi turnover.

Komitmen organisasi berpengaruh signifikan terhadap intensi turnover. Selain itu, kompensasi, pengembangan karir dan komitmen organisasi memiliki efek negatif yang signifikan terhadap niat turnover secara bersamaan. Komitmen organisasi juga merupakan variabel mediasi dari kompensasi dan pengembangan karir terhadap turnover intention. Kompensasi yang baik meliputi gaji, insentif, bonus, penghargaan dan didukung oleh iklim kerja yang nyaman baik dari fasilitas, sarana dan hubungan 
komunikasi antar karyawan serta pemberian kesempatan kepada karyawan untuk mengembangkan karir melalui peningkatan posisi jabatan akan berdampak pada meningkatnya komitmen karyawan terhadap rumah sakit.

\section{Pengaruh Kompensasi terhadap Pengembangan Karir}

Hasil penghitungan statistik menggunakan AMOS diketahui bahwa terdapat pengaruh positif dan signifikan antara kompensasi terhadap pengembangan karir. Berdasarkan uji koefisien determinasi $\left(\mathrm{R}^{2}\right)$ dengan yang didapatkan dari variabel kompensasi terhadap pengembangan karir adalah sebesar 0,380 . Artinya variabel kompensasi mempengaruhi pengembangan karir sebesar $38 \%$, sedangkan sisanya $62 \%$ dipengaruhi oleh variabel lain diluar penelitian ini.

Berdasarkan analisis distribusi responden dengan three box methode, responden merasa rumah sakit memberikan penghargaan berupa pelatihan untuk meningkatkan kompetensi dan keterampilan mereka, namun dari sisi pendapatan, gaji yang mereka terima belum sesuai UMR. Pada variabel lainnya responden menyatakan tidak mendapatkan penghargaan dari rumah sakit walaupun prestasinya baik, dan sebagian dari responden menyatakan rumah sakit tidak memberikan kesempatan untuk melanjutkan pendidikan dengan biaya ditanggung rumah sakit. Insentif yang mereka dapatkan juga belum sesuai dengan kinerja mereka. Artinya hampir seluruh karyawan merasa rumah sakit tidak memberikan kompensasi atas prestasi dan kinerja baik yang dilakukan oleh karyawan, baik kompensasi berupa insentif ataupun penghargaan berupa pelatihan atau kesempatan menaikkan jenjang pendidikan dengan dibiayai oleh rumah sakit.

Kompensasi merupakan salah satu alasan terpenting yang membuat karyawan mau bertahan dan mengembangkan karir pada suatu perusahaan. Salah satu tujuan pemberian kompensasi adalah meningkatkan produktivitas kerja, dimana pemberian kompensasi yang semakin baik akan mendorong karyawan untuk bekerja secara produktif. Menurut Moreno et al 10, kompensasi adalah segala sesuatu yang diterima oleh pekerja sebagai balas jasa atas kerja keras mereka. Kompensasi yang rendah dapat membuat karyawan tidak memiliki motivasi untuk bertahan dan mengembangkan karirnya, sebaliknya dengan kompensasi yang sesuai baik kompensasi langsung ataupun tidak langsung, merupakan salah satu faktor yang dapat membuat seorang karyawan bertahan bekerja dirumah sakit dan mengembangkan karir sesuai tingkat kompetensi dan keterampilannya.

\section{Pengaruh Iklim Kerja terhadap Pengembangan Karir}

Berdasarkan hasil pengujian statistik pada nilai estimate dan $p$ value diketahui bahwa iklim kerja berpengaruh positif dan signifikan terhadap pengembangan karir. Berdasarkan nilai $\mathrm{R}^{2}$ iklim kerja memberikan pengaruh $35,7 \%$ terhadap pengembangan karir, sisanya $64,3 \%$ dipengaruhi oleh variabel lain diluar penelitian. Berdasarkan analisis deskriptif dengan three box method, banyak responden menyatakan antar karyawan di rumah sakit saling mengenal dan berkomunikasi seperti keluarga sendiri, namun fasilitas dan sarana yang disediakan rumah sakit dirasakan kurang mendukung pekerjaan mereka.

Pada variabel lain sebagian responden menilai peraturan dan kebijakan yang dikeluarkan di rumah sakit mendukung kesehatan dan keselamatan kerja. Artinya masih terdapat karyawan yang merasa manajemen rumah sakit X Cisauk Tangerang belum memiliki peraturan dan kebijakan yang mendukung kesehatan dan keselamatan kerja karyawan. Sebagian dari responden juga mengeluhkan suasana kerja mereka kurang kondusif dan membuat mereka kurang konsentrasi dalam bekerja. Artinya tingkat kenyamanan karyawan dalam bekerja di rumah sakit $\mathrm{X}$ Cisauk Tangerang rendah tetapi pada indikator sosial tingkat kenyamanan karyawan cukup tinggi dikarenakan hubungan dan komunikasi antar karyawan berjalan baik dan dapat 
bekerjasama dengan baik.

Iklim kerja merupakan penggambaran suatu kualitas, suasana dan karakter yang terlihat pada norma dan nilai, hubungan interpersonal, suasana belajar mengajar, struktur organisasi, ikatan positif dengan lembaga dan lingkungan fisik yang ada di lembaga tempat karyawan bekerja. Suatu iklim kerja bisa diukur dengan cara dimensi safety (rasa aman), teaching and learning (kegiatan belajar mengajar), interpersonal relationships (hubungan dengan orang lain) dan institutional environment (lingkungan kerja). Salah satu kegiatan belajar di dalam suatu organisasi adalah pelatihan terhadap karyawan, di mana dengan pelatihan dapat membantu karyawan dalam melakukan pengembangan karirnya.

Hasil penelitian Ahyauddin dapat disimpulkan bahwa ada pengaruh positif dan signifikan pelatihan terhadap pengembangan karir, terdapat pengaruh positif dan signifikan motivasi kerja terhadap pengembangan karir, terdapat pengaruh positif dan signifikan motivasi dan pelatihan secara bersama-sama terhadap pengembangan karir. ${ }^{11}$ Iklim kerja yang nyaman dengan disukung oleh prasarana yang dapat mendukung mutu dan kelancaran pelayanan dapat membuat karyawan memiliki motivasi untuk bertahan dan mengembangkan karirnya.

\section{Pengaruh Pengembangan Karir terhadap Komitmen Organisasi}

Berdasarkan hasil pengujian statistik disimpulkan bahwa pengembangan karir berpengaruh positif dan signifikan terhadap komitmen organisasi Nilai $\mathrm{R}^{2}$ menghasilkan pengaruh pengembangan karir terhadap komitmen organisasi sebesar 40,9\% dan sisanya $59,1 \%$ dipengaruhi variabel lainnya. Berdasarkan hasil tersebut maka dapat disimpulkan bahwa semakin tinggi pengembangan karir menjadikan komitmen organisasi semakin tinggi.

Responden banyak mengungkapkan atasan memberikan kesempatan yang sama terhadap setiap karyawan untuk berkarir, namun sistem promosi yang ada di rumah sakit masih belum sesuai harapan. Artinya sistem pengembangan karir di rumah sakit sudah berjalan, tetapi tingkat sistem promosi pengembangan karir yang dibuat oleh manajemen rumah sakit belum sesuai dengan harapan karyawan. Sebagian responden menyatakan bahwa sistem pengembangan karir yang dijalankan di rumah sakit belum sesuai harapan, namun ketika ada informasi posisi yang kosong, perusahaan selalu menginformasikan kepada karyawan. Artinya walaupun rumah sakit selalu memberikan informasi promosi jabatan secara terbuka, namun karyawan masih belum merasa sistem pengembangan karir di rumah sakit berjalan baik.

Hasil kesimpulan di atas didukung oleh teori kebutuhan Maslow yang mengemukakan mengenai berbagai kebutuhan dasar manusia yang wajib dipenuhi lebih dahulu kemudian dilanjutkan dengan kebutuhan berikutnya. Berdasarkan atas apa yang dikemukakan Abraham Maslow khususnya pada teori hirarki kebutuhan Maslow, pemenuhan kebutuhan didorong oleh motivasi. Motivasi dalam hal ini adalah motivasi kekurangan (deficiency growth) dan perkembangan (motivation growth). Ada lima tingkatan kebutuhan yang dikemukakan oleh teori kebutuhan Maslow, diantaranya kebutuhan fisiologis, rasa aman, sosial, penghargaan dan aktualisasi diri. Kelima kebutuhan tersebut disusun pada teori kebutuhan Maslow secara bertingkat dari yang paling mendasar (fisiologis/fisik) hingga yang tertinggi (aktualisasi diri).

Pengembangan karir merupakan penerapan teori kebutuhan Maslow pada kebutuhan akan penghargaan, dimana pada manajemen perusahaan kondisi karyawan pada pemenuhan kebutuhan penghargaan ini adalah terkait dengan jabatan yang lebih tinggi. Posisi tertentu akan membuat karyawan merasa dirinya dihargai, disegani dan dihormati. Sehingga karyawan yang telah terpenuhi kebutuhan dasar sebelumnya akan bekerja lebih giat untuk melampaui target demi memperoleh promosi jabatan. Teori kebutuhan Maslow ini digunakan oleh para 
manajer untuk mempromosikan bawahan dengan syarat tertentu. Hal ini akan menjadikan bawahannya merasa dihargai atas kerjanya ditambah dengan promosi yang membuat kebutuhan akan harga dirinya terpenuhi.

Hasil penelitian Weng et al memberikan hasil keempat dimensi pertumbuhan karir berhubungan positif komitmen afektif, dan bahwa ketiga aspek berhubungan positif dengan komitmen berkelanjutan dan komitmen normatif. ${ }^{12}$ Karena tujuan akhir karir behubungan dengan ketiga bentuk komitmen, manajer disarankan untuk mempertimbangkan tujuan akhir karir pada saat perekrutan, seleksi, dan proses penempatan karyawan. Pengembangan karir (pendampingan dan peningkatan kualitas pekerjaan) meningkatkan komitmen karyawan. ${ }^{4}$

Studi ini merekomendasikan manajer sumber daya manusia harus memasukkan mentoring dan peningkatan kualitas pekerjaan sebagai faktor-faktor yang dapat meningkatkan pengembangan karir karyawan mereka yang nantinya meningkatkan komitmen mereka untuk mencapai tujuan organisasi. Ramli et al juga menyatakan hal yang sama bahwa pengembangan karir yang tinggi berdampak secara signifikan pada komitmen organisasi. ${ }^{13}$ Begitu pula dengan komitmen organisasi yang tinggi akan berdampak secara signifikan pada kinerja karyawan. Akhirnya hasil uji tidak langsung pada pengembangan karir dapat meningkatkan kinerja karyawan secara signifikan yang didukung oleh komitmen organisasi karyawan yang tinggi. Terpenuhinya kebutuhan karyawan akan penghargaan yang diberikan oleh rumah sakit atas prestasi kerja karyawan, dapat memberikan dampak pada peningkatan komitmen karyawan terhadap rumah sakit.

\section{Pengaruh Kompensasi terhadap Komitmen Organisasi}

Berdasarkan hasil penelitian didapatkan kompensasi berpengaruh positif dan signifikan terhadap komitmen organisasi. Dari nilai $\mathrm{R}^{2}$ pengaruh kompensasi terhadap komitmen organisasi sebesar $27,6 \%$, sisanya $72,4 \%$ dipengaruhi variabel lainnya. Pengaruh kompensasi terhadap komitmen organisasi secara langsung sebesar 0,276, sedangkan apabila dimediasi oleh pengembangan karir didapatkan nilai 0,155 (PL > PT; 0,276 < 0,146). Kesimpulan yang dapat diambil adalah kompensasi dapat meningkatkan komitmen organisasi tanpa harus di mediasi pengembangan karir. Berdasarkan hasil tersebut maka dapat disimpulkan bahwa kompensasi berpengaruh secara langsung terhadap komitmen organisasi. Kompensasi merupakan cara perusahaan untuk meningkatkan kualitas karyawannya untuk pertumbuhan perusahaan. Setiap perusahaan memiliki suatu sistem kompensasi yang berbeda-beda sesuai dengan visi, misi, dan tujuannya.

Berdasarkan analisa deskriptif dengan menggunakan three box method pada variabel kompensasi, banyak karyawan merasa gaji yang didapatkan tidak mampu memenuhi kebutuhan mereka, serta tidak sesuai dengan latar belakang yang mereka miliki. Artinya hampir seluruh karyawan merasa gaji yang diberikan oleh rumah sakit belum mampu memenuhi kebutuhan hidup mereka dan tidak sesuai dengan pendidikan dan pengalaman yang dimiliki. Pada indikator bonus, karyawan menyatakan bonus yang diterima tidak sesuai dengan harapan, hal ini juga terjadi pada indikator insentif yang mereka nilai tidak sesuai dengan waktu dan tenaga yang telah diberikan. Di sisi yang sama, bonus yang diterima tidak rutin diberikan oleh rumah sakit setiap tahunnya. Artinya berdasarkan variabel kompensasi dari indikator gaji, insentif, bonus dan penghargaan belum sesuai dengan harapan karyawan.

Kompensasi memberikan efek positif dan signifikan terhadap komitmen organisasi. 6,9,14,15 Manajemen kompensasi mengarah pada kinerja yang lebih baik, peningkatan manajemen, hubungan kerja yang baik antara pengusaha dan karyawan dan meningkatkan komitmen organisasi di tempat kerja. Kepuasan kerja dapat membuat karyawan tetap loyal dan berkomitmen Ada hubungan 
langsung yang kuat antara kompensasi dan organisasi komitmen dalam organisasi. Tujuan utama dari penelitian ini adalah untuk membangun hubungan antara kompensasi komitmen manajemen dan organisasi karyawan. Kee et al menyatakan ada hubungan yang signifikan antara kompensasi finansial seperti gaji, bonus dan gaji dan komitmen organisasi. ${ }^{16}$ Selain itu, upah berbasis prestasi diidentifikasi sebagai faktor dominan dalam mempengaruhi komitmen organisasi.

Pada penelitian yang dilakukan Nawab dan Bhatti, memberikan kesimpulan hubungan antara kompensasi karyawan dan kepuasan kerja menunjukkan hubungan positif dan signifikan hubungan antara kompensasi karyawan dan komitmen organisasi karyawan yang menunjukkan hubungan positif yang signifikan satu sama lain. ${ }^{17}$ Kompensasi sebagai salah satu faktor pembentuk komitmen karyawan, dimana ketika karyawan mendapatkan pendapatan sebagai imbalan atas tenaga atau pikiran yang dicurahkan untuk mencapai tujuan rumah sakit dan dapat memenuhi kebutuhan hidup baik untuk dirinya dan keluarganya akan menjadikan rasa keterikatan karyawan terhadap rumah sakit.

\section{Pengaruh Iklim Kerja terhadap Komitmen Organisasi}

Hasil perhitungan pengujian statistik menggunakan AMOS-path analysis diketahui bahwa iklim kerja berpengaruh positif dan signifikan terhadap komitmen organisasi. Dari nilai $\mathrm{R}^{2}$ pengaruh kompensasi terhadap komitmen organisasi sebesar $27,6 \%$, sisanya $72,4 \%$ dipengaruhi variabel lainnya. Pengaruh iklim kerja terhadap komitmen organisasi secara langsung sebesar 0,218, sedangkan apabila dimediasi oleh pengembangan karir didapatkan nilai 0,146 (PL > PT; 0,218 < 0,146). Dapat disimpulkan iklim kerja dapat meningkatkan komitmen organisasi tanpa harus di mediasi pengembangan karir.

Berdasarkan analisa deskriptif dengan three box method, responden lebih banyak yang setuju bahwa rumah sakit mendukung setiap perubahan ataupun kreatifitas untuk mencapai tujuan rumah sakit, serta sebagian responden menyatakan Standar Operasional Prosedur yang dikeluarkan rumah sakit dijalankan dengan patuh oleh semua karyawan. Berdasarkan hasil analisa deskriptif diatas dapat disimpulkan bahwa karyawan merasakan rumah sakit kurang mendukung setiap usaha karyawan untuk mencapai tujuan rumah sakit dan budaya kerja untuk menjalankan standar operasional prosedur belum dijalankan oleh semua karyawan.

Kepuasan kerja akan lebih baik ketika di dalam suatu organisasi para pekerjanya memiliki komitmen organisasional yang tinggi dalam organisasi sehingga mereka dapat bekerjasama dengan baik dan nyaman ${ }^{18}$. Hasil penelitian ini sama dengan penelitian Attia et al ${ }^{7}$, dan Asyari et al ${ }^{19}$. Dimana lingkungan kerja berpengaruh postif terhadap komitmen organisasi. Lingkungan yang sehat akan meningkatkat komitmen organisasi. Faktor saran pelayanan sebagai bagian dari iklim kerja dapat mempengaruhi mau atau tidaknya seorang karyawan terikat pada rumah sakit, dengan dipenuhinya segala jenis perlengkapan kerja serta fasilitas yang berfungsi sebagai alat utama atau pembantu dalam pelaksanaan pekerjaan, akan memperlancar pelaksanaan pelayanan sehingga karyawan dapat menjalani pekerjaan dengan nyaman, efektif dan efisien. Pada akhirnya akan berdampak pada terbentuknya ikatan atau komitmen karyawan terhadap rumah sakit.

\section{KESIMPULAN}

Kompensasi dan iklim kerja berpengaruh positif signifikan terhadap pengembangan karir. Pengembangan karir, kompensasi, dan iklim kerja berpengaruh positif signifikan terhadap komitmen organisasi. Sehingga Berdasarkan hasil penelitian rumah sakit dapat mengadakan sistem renumerasi beban kerja, masa kerja, pendidikan, pengalaman, serta prestasi kerja karyawan. Pemberian reward berupa pelatihan dan pengembangan keterampilan untuk mereka yang berprestasi sehingga dapat memotivasi karyawan untuk memiliki prestasi 
dalam bekerja. Karyawan juga diberikan kesempatan untuk meningkatkan kompetensi dengan pelonggaran jam kerja kepada mereka yang mengikuti sekolah atau pelatihan agar bersertifikasi sesuai kebutuhan rumah sakit.

Rumah sakit harapannya memberikan fasilitas untuk menunjang pekerjaan agar menjadi lebih efektif dan efisien salah satunya dengan perbaikan dan penyempurnaan sistem informasi rumah sakit (SIMRS) dan menjadi sistem yang terintegrasi. Untuk meningkatkan psikologis karyawan dapat dilakukan dengan pemberian reward terhadap karyawan sesuai dengan prestasi dan kinerjanya. Reward tersebut dapat berupa kompensasi tidak langsung berupa pelatihan, reward pendidikan untuk mendapatkan career path yang lebih baik dan beberapa hal lain. Pemberian reward juga memungkinkan untuk munculnya sikap daya saing antar karyawan, yang diharapkan karyawan akan memiliki daya juang dan senantiasa meningkatkan kualitas diri sebagai bentuk bakti terhadap rumah sakit.

\section{UCAPAN TERIMA KASIH}

Penulis menyampaikan penghargaan setinggi-tingginya dan terima kasih kepada Dr. dr. Ratna Indrawati, MKes dan Drh. Cri S Prajna Wekadigunawan, MPH, Ph.D sebagai pembimbing serta Dr. Rokiah Kusumapradja, SKM.,MHA sebagai ketua program studi Magister Administrasi Rumah Sakit Universitas Esa Unggul, yang telah banyak memberi dukungan, bantuan dan motivasi sejak perkuliahan dimulai sampai penulisan tesis ini.

\section{DAFTAR PUSTAKA}

1. Nguyen TN, Mai KN, Nguyen $P$ V. Factors affecting employees' organizational commitment-A Study of banking staff in Ho Chi Minh City, Vietnam. J Adv Manag Sci 2014; 2: 7-11.

2. Teresa R, Evienia B. Pengaruh komitmen organisasional terhadap kepuasan kerja karyawan CV Karya Taruna Teknik. In: Gunawan A (ed) Prosiding Working Papers Series In Management. Jakarta, 2017, pp. 113-122.

3. Massie R, Tewal B, Sendow G. Pengaruh perencanaan karir, pelatihan dan pengembangan karir terhadap kinerja pegawai pada Museum Negeri Provinsi Sulawesi Utara. J Berk Ilm Efisiensi 2015; 15: 635-645.

4. Dialoke I, Wabara A. Career Development and Employee Commitment: A study of selected higher institutions in Abia State. IOSR J Bus Manag e-ISSN 2017; 22-27.

5. Hasibuan MS. Manajemen sumber daya manusia. Jakarta: PT Haji Masagung, 2006.

6. Daniel CO. Compensation management and its impact on organizational commitment. Int J Contemp Appl Res 2019; 6: 26-36.

7. Attia MAS, Youseff MRL, Fatah SAMA El, et al. The relationship between health care providers' perceived work climate, organizational commitment, and caring efficacy at pediatric intensive care units, Cairo University. Int $J$ Health Plann Manage 2020; 35: 469-481.

8. Budiningsih S, Warso MM, Yulianeu Y. Hubungan Pengembangan Karir dan Kompensasi Terhadap Kepuasan Kerja dan Implikasinya Pada Komitmen Organisasional PT. Pertani (Persero), Wilayah Jateng \& DIY. J Manage; 3.

9. Solihin, Aima MH, Widyastuti T. The Impact of Compensation and Career Development on the Organizational Commitment and the Implication on Employee's Turnover Intention of $\mathrm{Pt}$ Serasi Autoraya Head Office. Int J Innov Sci Res Technol 2019; 4: 147-157.

10. Sanchez Moreno J, Ramirez Munoz D, Cardoso S, et al. A non-invasive thermal drift compensation technique applied to a spin-valve magnetoresistive current sensor. Sensors 2011; 11: 2447-2458.

11. Ahyauddin. Pengaruh pelatihan dan motivasi kerja terhadap pengembangan karir serta implikasinya pada kinerja pegawai Dinas Pekerjaan Umum Pengairan Provinsi Sumatra Utara. $J$ Ekon dan Bisnis STIE YPN; 7.

12. Weng Q, McElroy JC, Morrow PC, et al. The relationship between career growth 
and organizational commitment. $J$ Vocat Behav 2010; 77: 391-400.

13. Ramli AH, Yudhistira R. Pengaruh Pengembangan Karir terhadap Kinerja Karyawan melalui Komitmen Organisasi pada PT. Infomedia Solusi Humanika di Jakarta. In: Prosiding Seminar Nasional Cendekiawan. 2018, pp. 811-816.

14. Asuah-Duodu E, Smith SP, Thein PWL. Relationship of Job Design, Organizational Commitment on Compensations of Physicians In A Private Hospital, Philippines. In: Abstract Proceedings International Scholars Conference. 2019, pp. 1067-1086.

15. Azis E, Prasetio AP, Putri AD. FACTORS AFFECTING ORGANIZATIONAL COMMITMENT IN PHARMACY INDUSTRY: THE ROLE OF COMPENSATION AND LEARNING CULTURE AS PREDICTORS. In: Proceeding of International Seminar \& Conference on Learning Organization. 2018.

16. Kee LB, bin Ahmad R, Abdullah SM. Relationship between financial compensation and organizational commitment among Malaysian bank workers. Asian Bus Res 2016; 1: 75.

17. Nawab S, Bhatti KK. Influence of employee compensation on organizational commitment and job satisfaction: A case study of educational sector of Pakistan. Int J Bus Soc Sci; 2.

18. Luthans F. Organization behaviour. New York: McGraw Hill International, 2014.

19. Asyari A, Seputro A, Paramita PD. The effect of transformational leadership, work enviroment, and compensation style on organizational commitments to improve work satisfaction of employees in PT Nusatovel Kantor Semarang Center. J Manage; 5. 